\title{
Retrograde conduction in complete atrioventricular block Study using His bundle recordings
}

\author{
P. Touboul, F. Huerta, ${ }^{1}$ and J. P. Delahaye \\ From the Laboratory of Clinical Electrophysiology, Hôpital Cardio-vasculaire et Pneumologique, Lyon, France
}

Using His bundle recordings and ventricular stimulation retrograde conduction was studied in 57 cases of complete AV block. VA conduction was observed in 13 patients. Of the 13,12 had AV block distal to H, and during cardiac pacing 5 of them showed a retrograde His bundle potential. In all cases the AV node-His pathway was implicated in the transmission of the retrograde impulse. There was no retrograde atrial response in the remaining patients. VA block usually occurred at the same level as $A V$ block. Nevertheless, two cases of $A V$ block distal to $H$ were associated with concealed retrograde conduction which stopped within the $A V$ node.

Inverted atrial depolarizations in advanced or complete atrioventricular (AV) block could be regarded as paradoxical. They suggest a persisting ventriculoatrial (VA) conduction while forward transmission is interrupted. Such phenomena have always been considered rare. Ten years ago Scherf and Cohen (1964), reviewing the published reports, found 81 cases, including the first clinical report by Cohn and Fraser (1913).

The use of cardiac stimulation in the treatment of AV block has enabled the 'reversed conduction' phenomenon to be observed more often. Thus, Adams (1963) noted the occurrence of retrograde $P$ waves after the insertion of a ventricular pacemaker in a patient with complete AV block. Other cases have been reported since (Hafemeister and von Knorre, 1968; Santoli et al., 1969; Puech et al., $1970 \mathrm{~b})$. The recent development of clinical electrophysiological studies has also brought added interest in this field (Castillo and Samet, 1967; Goldreyer and Bigger, 1970).

In the present investigation retrograde conduction in complete heart block was studied during ventricular pacing. Recordings of $\mathrm{His}$ bundle activity were made to localize the site of AV and VA block and to identify the pathways of retrograde conduction.

Received 1 September 1975.

IPresent address: Avenida 308, no 46, Castelldefels, Barcelona, Spain.

\section{Subjects and methods}

All of the 57 patients included in the study had been admitted between January 1972 and March 1973 to the intensive care unit for syncope resulting from complete AV block. Informed consent was obtained from each patient. There were 21 men and 36 women ranging in age from 36 to 85 years (average 71 ). The external electrocardiogram showed atrial activity originating in the sinus node and a ventricular escape rhythm, the rate of which ranged from 30 to 65 per minute. The QRS complexes were narrow in 10 cases and wide in 47 .

The electrophysiological study included the recording of the His bundle potential $(\mathrm{H})$ by Scherlag's method (Scherlag et al., 1969). The proximal terminals of the electrode-catheter were connected to the input of an electrocardiograph amplifier (recording frequencies 50 to $700 \mathrm{~Hz}$ ). A bipolar atrial electrogram was simultaneously recorded via an electrode-catheter positioned at the upper part of the right atrium. Complete abs znce of $\mathrm{AV}$ conduction was checked by atrial pacing at increasing rate. Right ventricular pacing was initiated at a rate slightly faster than the spontaneous heart rate, and increased by increments of 10 to 20 beats/min up to $160 / \mathrm{min}$. The impulses, $2 \mathrm{~ms}$ in duration, were delivered by a Medtronic 5837 stimulator at twice diastolic threshold intensity.

The studies were carried out in the postabsorptive non-sedated state. Each patient was under continuous monitoring. Lead II was visualized on an oscilloscope. An Elema four-channel recorder was used. The paper speed was 50 to $100 \mathrm{~mm} / \mathrm{s}$. At the end of the study the ventricular catheter was usually left in place until the insertion of a permanent pacemaker. 


\section{Definition of terms}

The site of the AV block was defined as follows (Puech et al., 1970a; Narula et al., 1971).

1) Block proximal to $H$, involving the AV node or the initial part of the main bundle. The electrogram of the His bundle was dissociated from the atrial activity but preceded each ventricular escape complex.

2) Block at the $\mathrm{H}$ recording site-that is, in the main bundle itself. The His potential was divided into two independent components, one of which followed atrial activity and the other initiated ventricular rhythm.

3) Block distal to $\mathrm{H}$, located either at the extremity of the main bundle or in both branches. The His bundle electrogram followed each atrial wave and was independent of the ventricular impulses.

$\mathrm{A}$ and $\mathrm{V}$ represented, respectively, the atrial and ventricular activities recorded in the His bundle lead.

Similarly, the level of the retrograde block was defined in relation to the $\mathrm{H}$ deflection. The VA block was assumed to be infra- or intra-Hisian if an unchanged $\mathrm{AH}$ conduction persisted during ventricular pacing. On the other hand, a supra-Hisian VA block was defined by the absence of $\mathbf{H}$ deflection following the atrial activity, the retrograde $\mathrm{His}$ bundle depolarization $\mathrm{H}^{\prime}$ being included in, or observed after the ventricular activity.

In VA conduction the atrial activation sequence was reversed: the $A$ wave in the His bundle lead then preceded the high atrial electrogram.

\section{Results}

Of the 57 cases with complete AV block 3 were proximal to $H, 11$ involved the main bundle, and 43 were distal to the recording site of the His bundle activity. VA conduction was present in 13 patients (22\%) (Table); 12 of them had an AV block distal to $\mathrm{H}$ (Fig. 1, 3, and 4) and only one proximal to $\mathrm{H}$ (Fig. 2). No retrograde conduction to the atria was observed in the remaining group. The VA block was located at the same level as the AV block. However, two cases of infra-Hisian block showed an intermittent retrograde conduction to the His bundle and to the AV node (Fig. 5).

\section{Discussion}

The inverted atrial responses sometimes seen in high-grade AV block are usually explained by the persistence of retrograde conduction to the atria, despite complete, or nearly complete, interruption of the AV conduction. Other theories based on the influence of the ventricular contraction on the atrial activity or the passive propagation of electrotonic currents (Scherf, 1959) are more questionable. To explain the 'reversed conduction' phenomenon, Danielopolu and Danulesco (1922) postulated the existence of two anatomically distinct pathways for forward and retrograde conduction. Recent clinical

TABLE Data on 13 patients with retrograde conduction

\begin{tabular}{|c|c|c|c|c|c|c|c|c|c|c|c|c|}
\hline \multirow[b]{2}{*}{ No. } & \multirow[b]{2}{*}{$\begin{array}{l}\text { Age, } \\
\text { sex }\end{array}$} & \multicolumn{2}{|c|}{$Q R S$ complex } & \multicolumn{9}{|c|}{ His bundle study } \\
\hline & & $\begin{array}{l}\text { Shape } \\
\text { in } V 1\end{array}$ & Duration & $\begin{array}{l}\text { Site } \\
\text { of block }\end{array}$ & $P P$ & $R R$ & $A H$ & $H V$ & $\begin{array}{l}\text { Pacing } \\
\text { cycle length }\end{array}$ & $V A$ & $V H^{\prime}$ & $H A$ \\
\hline 1 & $60 \mathrm{M}$ & RBBB & 160 & Distal & 700 & 1800 & 85 & 一 & $\begin{array}{l}780 \\
520\end{array}$ & $\begin{array}{l}160 \\
B\end{array}$ & 一 & 一 \\
\hline 2 & $65 \mathrm{~F}$ & Normal & 100 & Proximal & 800 & 1370 & 一 & 30 & $\begin{array}{l}770 \\
520\end{array}$ & $\begin{array}{l}260 \\
\text { B }\end{array}$ & - & 一 \\
\hline 3 & $77 \mathrm{M}$ & RBBB & 190 & Distal & 770 & 1700 & 90 & 一 & $\begin{array}{l}720 \\
580\end{array}$ & $\begin{array}{l}260 \\
\text { B }\end{array}$ & - & 一 \\
\hline 4 & $68 M$ & RBBB & 200 & Distal & 600 & 1920 & 80 & 一 & $\begin{array}{l}560-520 \\
440\end{array}$ & $\begin{array}{l}140-160 \\
\text { B }\end{array}$ & 一 & 一 \\
\hline 5 & $74 \mathrm{~F}$ & RBBB & 170 & Distal & 510 & 1620 & 65 & - & $\begin{array}{l}480-400 \\
340\end{array}$ & $\begin{array}{l}160-200 \\
\text { B }\end{array}$ & $80-80$ & $80-120$ \\
\hline $\begin{array}{l}6 \\
7\end{array}$ & $\begin{array}{l}71 \mathrm{~F} \\
79 \mathrm{M}\end{array}$ & $\begin{array}{l}\text { LBBB } \\
\text { RBBB }\end{array}$ & $\begin{array}{l}150 \\
140\end{array}$ & $\begin{array}{l}\text { Distal } \\
\text { Distal }\end{array}$ & $\begin{array}{l}570 \\
740\end{array}$ & $\begin{array}{r}1500 \\
900\end{array}$ & $\begin{array}{r}55 \\
100\end{array}$ & 二 & $\begin{array}{l}550-300 \\
760-400 \\
345\end{array}$ & $\begin{array}{l}180-200 \\
120-180 \\
B\end{array}$ & $\begin{array}{l}150-160 \\
85-85\end{array}$ & $\begin{array}{l}30-40 \\
50-95\end{array}$ \\
\hline $\begin{array}{r}8 \\
9 \\
10 \\
11\end{array}$ & $\begin{array}{l}85 M \\
75 M \\
65 M \\
59 F\end{array}$ & $\begin{array}{l}\text { LBBB } \\
\text { LBBB } \\
\text { RBBB } \\
\text { LBBB }\end{array}$ & $\begin{array}{l}150 \\
180 \\
200 \\
180\end{array}$ & $\begin{array}{l}\text { Distal } \\
\text { Distal } \\
\text { Distal } \\
\text { Distal }\end{array}$ & $\begin{array}{l}620 \\
760 \\
750 \\
650\end{array}$ & $\begin{array}{l}1200 \\
1880 \\
1810 \\
1580\end{array}$ & $\begin{array}{r}70 \\
70 \\
180 \\
110\end{array}$ & $=$ & $\begin{array}{r}710-360 \\
760-380 \\
1090-630 \\
720-450 \\
420\end{array}$ & $\begin{array}{l}130-200 \\
? \\
180-180 \\
140-220 \\
\text { B }\end{array}$ & $\begin{array}{l}80-80 \\
= \\
-\end{array}$ & $\begin{array}{l}50-120 \\
- \\
-\end{array}$ \\
\hline 12 & $65 \mathrm{~F}$ & LBBB & 140 & Distal & 640 & 1150 & 140 & 一 & $\begin{array}{l}620-350 \\
340\end{array}$ & $\mathrm{~B}^{90-150}$ & - & - \\
\hline 13 & $66 \mathrm{M}$ & RBBB & 150 & Distal & 660 & 2120 & 105 & 一 & $\begin{array}{l}630 \\
560\end{array}$ & $\begin{array}{l}220 \\
B\end{array}$ & 75 & 145 \\
\hline
\end{tabular}

Abbreviations: VA: ventriculoatrial time; RBBB: right bundle-branch block; LBBB: left bundle-branch block; B: block; all measurements are in ms. 
FIG. 1 Case 1 (see Table). Complete block and ventricular escape rhythm with prolonged $Q R S$ complexes. The site of the block is distal to the His bundle potential (upper tracing). Ventricular stimulation produces 1:1 VA conduction (lower tracing). $B A E$ : bipolar right atrial electrogram. $H B E$ : His bundle electrogram. S: stimulation artefact. $H:$ His bundle activity.

FIG. 2 Case 2 (see Table): Complete AV block and ventricular escape rhythm with narrow $Q R S$ complexes. The AV conduction is interrupted proximal to the His bundle activity (upper tracing). Ventricular pacing is followed by retrograde conduction to the atria (lower tracing).

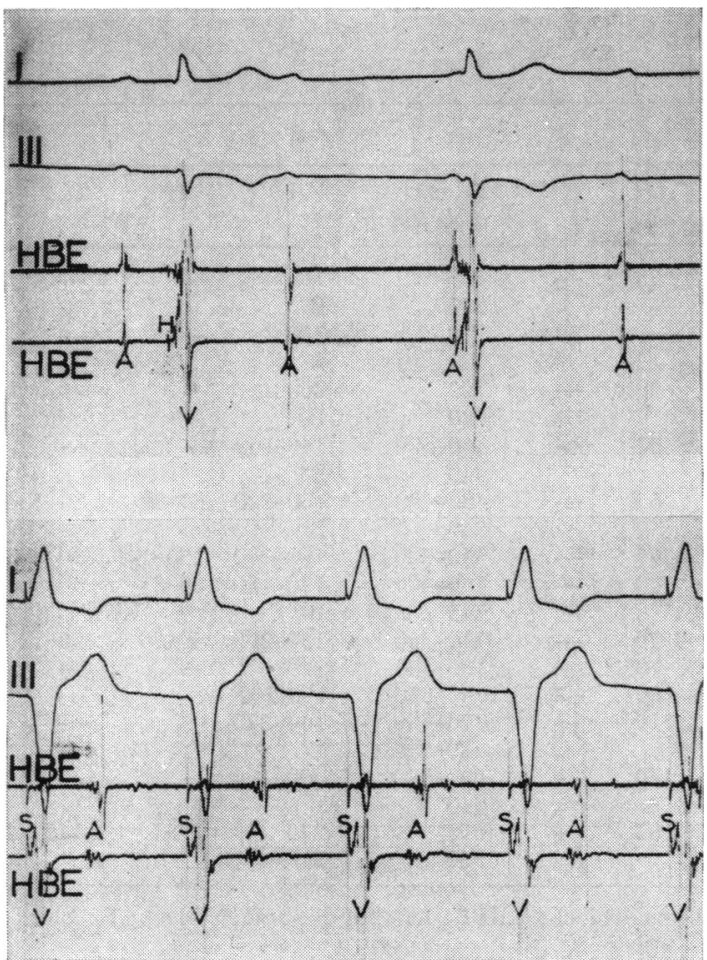

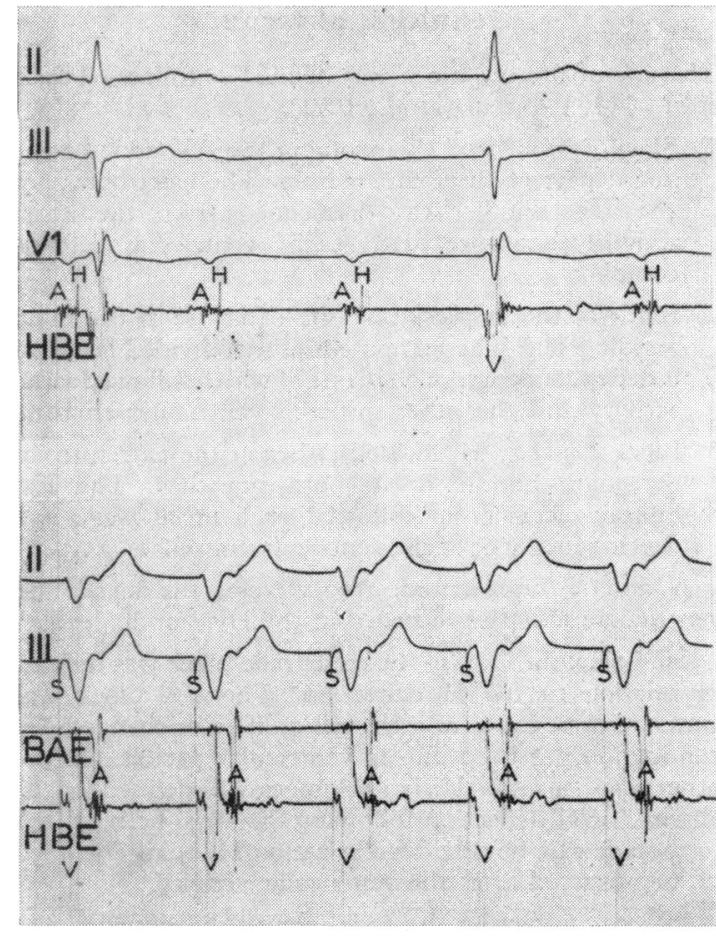

observations support this (Gupta and Haft, 1972; Coumel et al., 1973; Narula, 1974). However, an asymmetrical block could also be assumed in a damaged area of the specialized AV tissue, allowing conduction to occur in one direction but not in the other. Experimental studies by Mines (1913) and Ashman and Hafkesbring (1929) supported this hypothesis. Recordings of transmembrane potentials using microelectrodes have indicated unidirectional block in preparations of Purkinje fibres locally depressed by high concentrations of extracellular potassium (Cranefield, Klein, and Hoffman, 1971).

Although the occurrence of VA responses depends to a large extent on the lesions of the specialized pathways, other factors are implied in making the retrograde conduction manifest. Thus, a slow sinus rhythm increases the chances that a ventricular impulse will reach the atria during the phase of excitability. Conversely, the shortness of the sinus cycle length may prevent any retrograde depolarization. In our study the values of the PP control intervals were similar in patients with or without retrograde conduction, which minimizes the role of this factor in the results.

Likewise, the functional properties of the specialized tissue located proximal to the AV block 


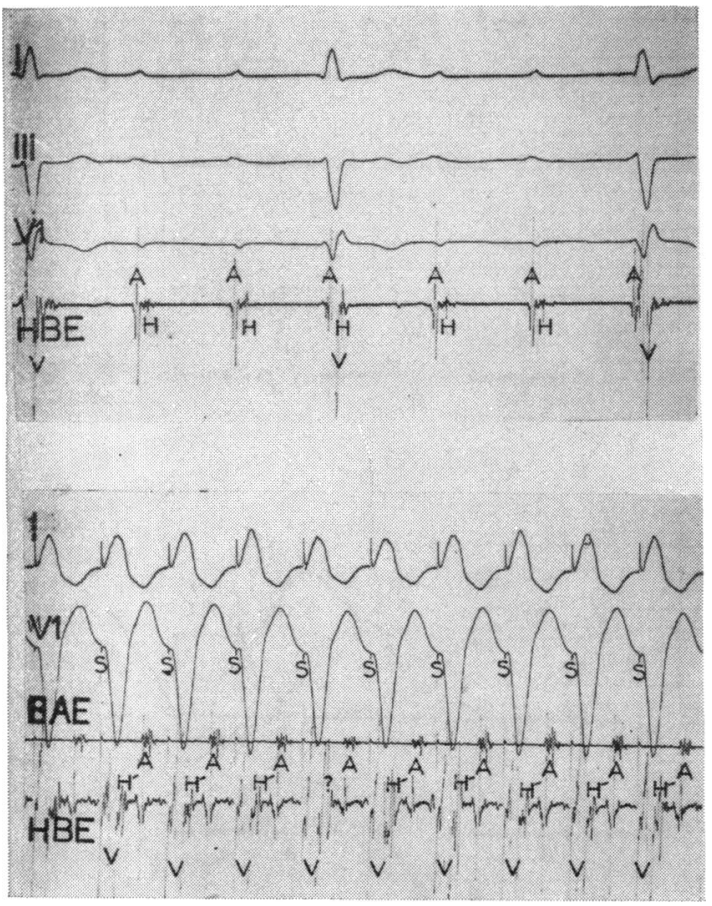

FIG. 3 Case 7 (see Table): Complete AV block distal to $H$ (upper tracing). Ventricular stimulation causes VA conduction. A retrograde His bundle potential $\left(H^{\prime}\right)$ is apparent after the paced $Q R S$ complexes (lower tracing).

FIG. 4 Case 13 (see Table): Complete AV block distal to $H$ (upper tracing). Ventricular pacing is followed by $1: 1 V A$ conduction. An $H^{\prime}$ deflection can be identified after each $Q R S$ complex (lower tracing).

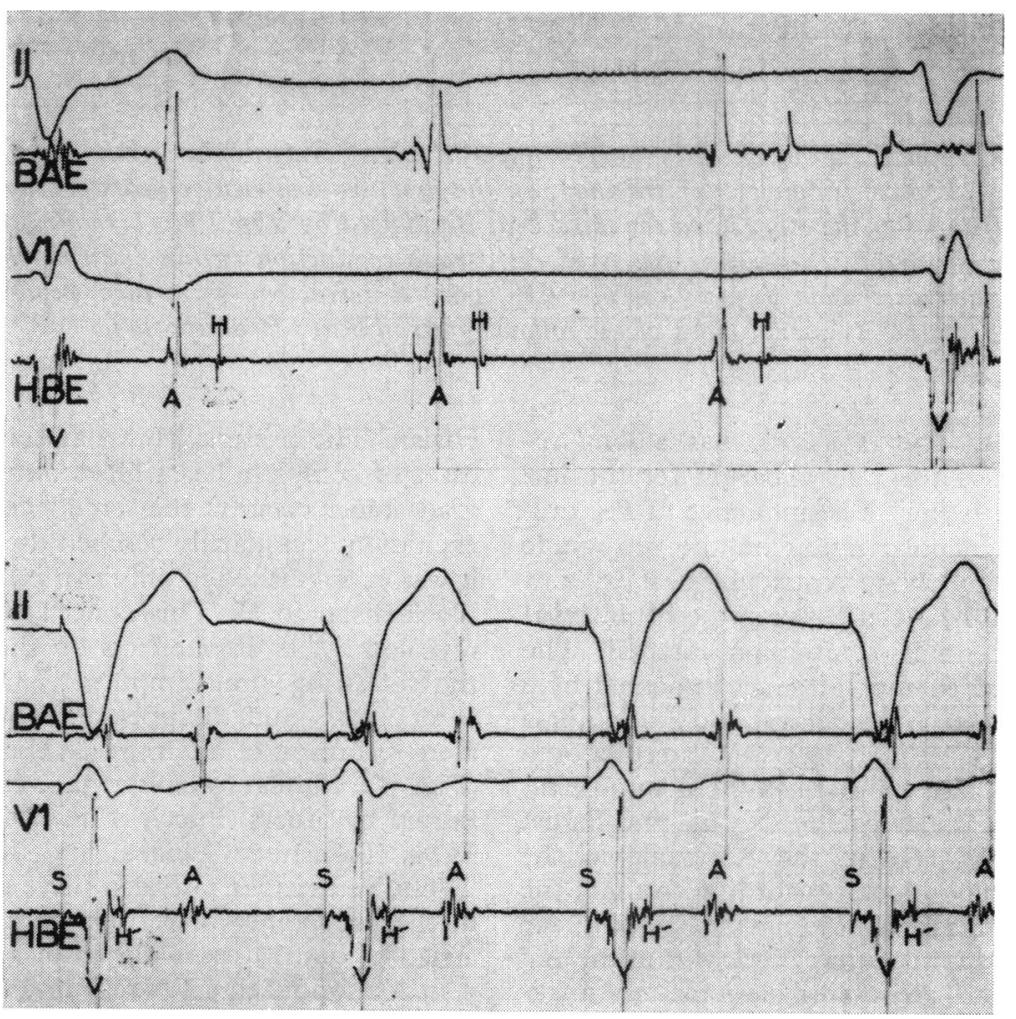




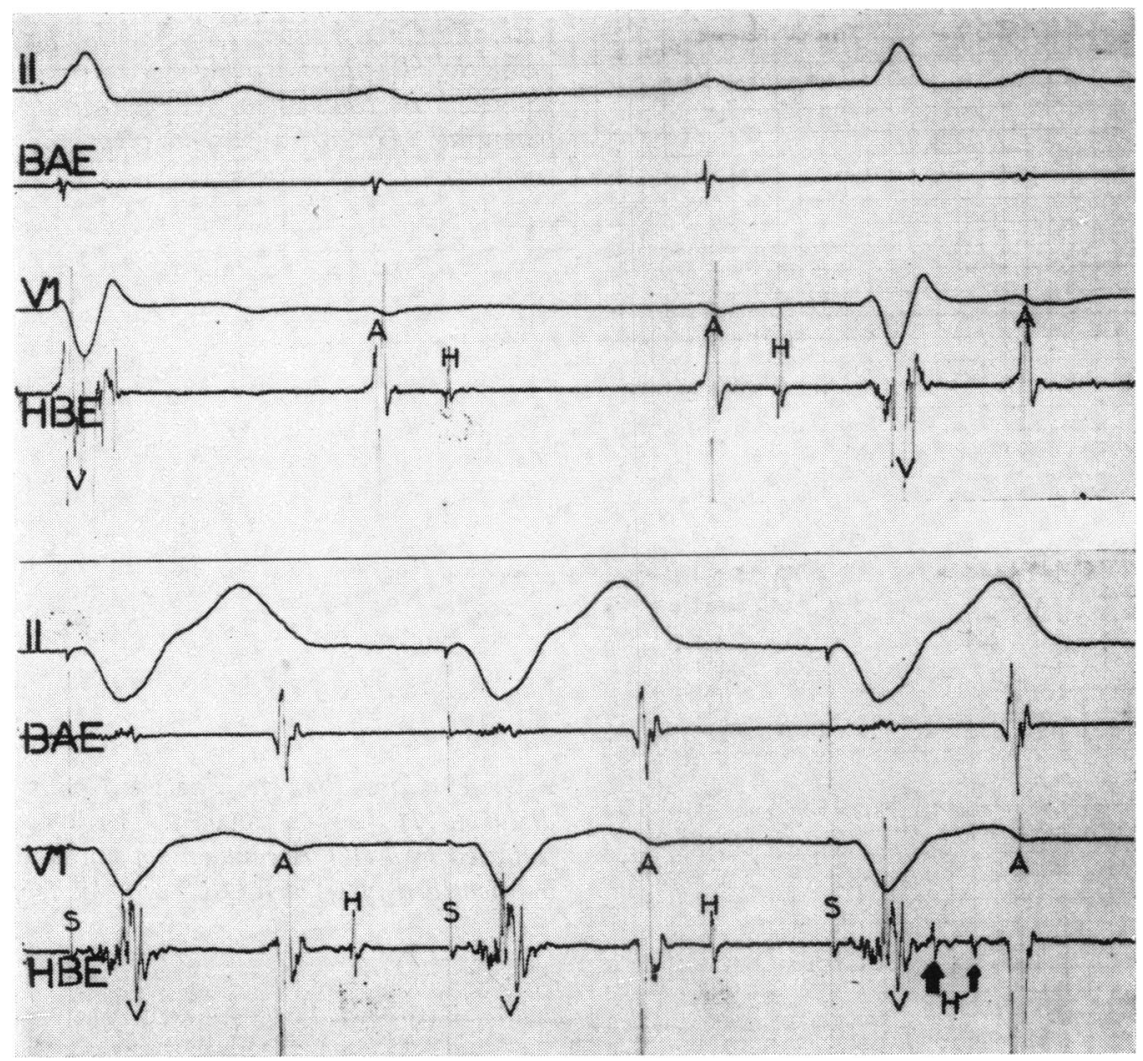

FIG. 5 Complete AV block distal to $H$ (upper tracing). Ventricular stimulation is accompanied by $A V$ dissociation (lower tracing). In the first two ventricular beats retrograde block is infra-Hisian. On the other hand the third beat is followed by a split His bundle potential (indicated by an arrow) suggesting impaired retrograde conduction within the common bundle. The concealed excitation dies within the $A V$ node. A refractory state then ensues which is responsible for the $A V$ nodal block of the following atrial beat : $H$ disappears.

can be important. The AV node has a long refractory period and the safety margin for the impulse conduction is low. The influence of the preceding AV node depolarization on the retrograde conduction of the following ventricular beat explains the relation sometimes seen between the PR interval and the RP retrograde conduction interval. The shortening of the PR interval is accompanied by a lengthening of the VA delay, and vice versa (Wolferth and McMillan, 1929; Winternitz and Langendorf, 1944). In a study using His bundle recordings and ventricular pacing, Narula and Samet (1970) stressed the role of the AV node in the genesis of retrograde block. According to them the sites of AV and VA block are not necesssarily the same. Retrograde impulse may block within the AV node, whereas the anatomical lesions are infra-
Hisian. The present work has shown that in most cases of complete heart block antegrade and retrograde block occur at the same level. The retrograde excitation occasionally reached the AV node, where it was extinguished in only two patients with an AV block distal to $H$. This concealed conduction was revealed by its after-effects on the transmission of the following sinus impulse: lengthening of $\mathrm{AH}$ in one case, and disappearance of $\mathrm{H}$ in the other after recording of a retrograde $\mathrm{His}$ bundle potential (Fig. 5). Similar phenomena were previously reported by others (Puech et al., 1974; Cohen et al., 1974; Takeshita, Tanaka, and Nakamura, 1974).

The ventricular rate also plays an important role in the occurrence of retrograde conduction to the atria. In our 13 cases electrical stimulation of the ventricles induced a VA response at a rate above the 
sinus rate. However, 5 of them showed intermittent VA conduction during spontaneous rhythm. If these findings are related to the site of the AV lesions unidirectional block was mainly found in cases with distal lesions of the His-Purkinje system. On the other hand, the main bundle blocks were bidirectional. Similar observations were made by Narula and Samet (1970).

During VA conduction the His bundle potential was usually buried in the QRS complex, except in 5 cases where it was visible. One patient showed a VA delay which affected the $\mathrm{VH}^{\prime}$ interval (150 to $160 \mathrm{~ms}$ ) but not the retrograde AV nodal conduction time ( $\mathrm{H}^{\prime} \mathrm{A}$ interval) (Table-Case 6). In the other cases the AV node was the main determinant of the retrograde delay inducing the rate-dependent increase in the VA time, then the impulse block. The participation of the AV node-His pathway in the retrograde conduction can also be shown by the use of pharmacological agents. Atropine and isoprenaline cause shortening of the VA time (Takeshita et al., 1974), whereas retrograde conduction is blocked by vagomimetic drugs (Puech et al., 1970b).

Finally, the mechanism of VA transmission is still not clearly understood. No definite conclusion arises from the present data. Unidirectional block in the damaged specialized area may be operative. However, the presence of Mahaim fibres bypassing the block area and functioning only in retrograde manner cannot be excluded.

\section{References}

Adams, C. W. (1963). Retrograde atrial conduction with complete heart block following implantation of an internal ventricular pacemaker. Diseases of the Chest, 43, 544.

Ashman, R., and Hafkesbring, R. (1929). Unidirectional block in heart muscle. American fournal of Physiology, 91, 65.

Castillo, C., and Samet, P. (1967). Retrograde conduction in complete heart block. British Heart fournal, 29, 553.

Cohen, S. I., Smith, L. K., Aroesty, J. M., Voukydis, P., and Morkin, E. (1974). Concealed retrograde conduction in complete atrioventricular block. Circulation, 50, 496.

Cohn, A. E., and Fraser, F. R. (1913). The occurrence of auricular contractions in a case of incomplete and complete heart-block due to stimuli received from the contracting ventricles. Heart, 5, 141.

Coumel, P., Gourgon, R., Slama, R., and Bouvrain, Y. (1973). Conduction auriculo-ventriculaire par des fibres de preexcitation associée à un bloc complet de la voie nodohissienne. Etude électrocardiographique de quatre cas. Archives des Maladies du Coeur et des Vaisseaux, 66, 285.

Cranefield, P. F., Klein, H. O., and Hoffman, B. F. (1971). Conduction of the cardiac impulse: I. Delay, block and one-way block in depressed Purkinje fibers. Circulation Research, 28, 199.

Danielopolu, D., and Danulesco, V. (1922). Sur la conducti- bilité rétrograde et sur la phase réfractoire de l'oreillette. Archives des Maladies du Coeur et des Vaisseaus, 15, 365.

Goldreyer, B. N., and Bigger, J. T. (1970). Ventriculo-atrial conduction in man. Circulation, 41, 935.

Gupta, P. K., and Haft, J. I. (1972). Retrograde ventriculoatrial conduction in complete heart block: studies with His bundle electrography. American fournal of Cardiology, 30, 408.

Hafemeister, G., and von Knorre, G. H. (1968). Rückläufige Erregungsleitung beim elektrisch stimulierten Herzen. 2. Mitteilung: retrograde Vorhoferregung und retrograde Reizleitungsstörungen. Zeitschrift für Kreislaufforschung, 57, 1131.

Mines, G. R. (1913). On dynamic equilibrium in the heart. Fournal of Physiology, 46, 349.

Narula, O. S. (1974). Retrograde pre-excitation. Comparison of antegrade and retrograde conduction intervals in man. Circulation, 50, 1129.

Narula, O. S., and Samet, P. (1970). Study of ventriculoatrial conduction by $\mathrm{His}$ bundle recordings in man. Circulation, 42, Suppl. 3, 47.

Narula, O. S., Scherlag, B. J., Samet, P., and Javier, R. P. (1971). Atrioventricular block. Localization and classification by His bundle recordings. American fournal of Medicine, 50, 146.

Puech, P., Slama, R., Grolleau, R., Motte, G., Dufoix, R., and Blames, P. (1970b). L'activité auriculaire rétrograde dans les blocs auriculo-ventriculaires de haut degré. Acta Cardiologica, 25, 443.

Puech, P., Grolleau, R., Latour, H., Dufoix, R., Cabasson, J., and Robin, J. (1970a). L'enregistrement de l'activité éléctrique du faisceau de His dans les blocs A-V spontanés. Archives des Maladies du Coeur et des Vaisseaux, 63, 784.

Puech, P., Grolleau, R., Cabasson, J., Baissus, C., and Latour, H. (1974). Les blocs auriculo-ventriculaires unidirectionnels. Etude par l'enregistement de l'électrogramme hisien. Archives des Maladies du Coeur et des Vaisseaux, 67, 1241.

Santoli, C., Mezzacapo, B., Distante, S., and Porciello, P. (1969). La conduzione retrograda nel blocco atrioventricolare completo trattato con stimolatore artificiale. Minerva Cardioangiologica, 17, 512.

Scherf, D. (1959). Retrograde conduction in complete heart block. Diseases of the Chest, 35, 320.

Scherf, D., and Cohen, J. (1964). Atrioventricular Node and Selected Cardiac Arrhythmias. Grune and Stratton, New York.

Scherlag, B. J., Lau, S. H., Helfant, R. H., Berkowitz, W. D., Stein, E., and Damato, A. N. (1969). Catheter technique for recording His bundle activity in man. Circulation, $39,13$.

Takeshita, A., Tanaka, S., and Nakamura, M. (1974). Study of retrograde conduction in complete heart block using His bundle recordings. British Heart fournal, 36, 462.

Winternitz, M., and Langendorf, R. (1944). Auriculoventricular block with ventriculoauricular response. Report of six cases and critical review of the literature. American Heart fournal, 27, 301.

Wolferth, C. C., and McMillan, T. M. (1929). Observations on the mechanism of relatively short intervals in ventriculoauricular and auriculoventricular sequential beats during high grade heart-block. American Heart fournal, 4, 521.

Requests for reprints to Dr. P. Touboul, Hupital Cardiovasculaire et Pneumologique, B. P. Lyon Montchat, 69394 Lyon Cédex 3, France. 